\title{
Modifiable and non-modifiable risk factors in ischemic stroke: a meta-analysis
}

\author{
Qinyuan Cui ${ }^{1}$, Niyaz Ahmad Naikoo ${ }^{2}$
}

1. Xingping people's hospital, No.15 jincheng road, xingping city, shaanxi province. China, 713100.

\begin{abstract}
Background: Stroke is a heterogeneous, multifactorial disease regulated by modifiable and non-modifiable risk factors like total cholesterol, triglycerides, high density lipid-cholesterol (HDL-C), low density lipid-cholesterol (LDL-C) and glucose and non-modifiable factors like age. Evaluation of these risk factors for ischemic stroke may contribute to more effective prevention. Methods: This meta-analysis investigated the data up to 2018 with respect to age, total cholesterol, triglycerides, high density lipid-cholesterol (HDL-C), low density lipid-cholesterol (LDL-C) and glucose levels in the Ischemic stroke patients and controls. Data from each eligible study was extracted such as year of publication, first author name, ethnicity/country, number of ischemic stroke patients and healthy controls and studies were subjected to heterogeneity analysis.

Results: Meta-analysis of the modifiable and non-modifiable risk factors like total cholesterol, HDL-C and LDL-C glucose, triglycerides levels and age were not having significantly associated with ischemic stroke $(\mathrm{p}>0.05)$. However meta-analysis of triglyceride yielded significant association ischemic stroke with overall 95\% CI (-0.62- $(-0.09)$ and $\mathrm{P}=0.007$ and glucose also showed significant association with ischemic stroke with $95 \% \mathrm{CI}(-1.08-(-0.14), \mathrm{P}=0.01$. Studies were subjected to heterogeneity which revealed significant heterogeneity with $(\mathrm{P}<0.00)$ and $\mathrm{I} 2>96 \%$.

Conclusion: Meta-analysis revealed that levels of triglyceride and glucose are the predisposing factors for ischemic stroke in the Asian population.

Keywords: Ischemic stroke, modifiable, non-modifiable, risk factors, meta-analysis.

DOI: https://dx.doi.org/10.4314/ahs.v19i2.36

Cite as: Cui Q, Naikoo NA. Modifiable and non-modifiable risk. factors in Ischemic stroke: meta-analysis. Afri Health Sci.2019;19(2): 2121 2129. https:// dx.doi.org/10.4314/abs.v19i2.36
\end{abstract}

\section{Introduction}

Ischemic stroke accounts for about $80 \%$ of the stroke population $^{1}$ and is a leading cause of mortality, presents a serious threat to public health ${ }^{2,3}$. Most strokes occur in people older than 70 years, rarely occuring in those below 35 years old ${ }^{4,5}$. Ischemic stroke is a multi-factorial disor$\operatorname{der}^{6}$. A number of risk factors are associated with an increased risk of stroke. They can be stratified into modifi-

\section{Corresponding author:}

Niyaz Ahmad Naikoo,

Department of Biotechnology

Govt. College for Women,

M.A Road Srinagar (Cluster University Srinagar)

J\&K India 190001

Tel: +91 7006276920/+919906504178

Email: drniyaznaik@gmail.com able and non-modifiable risk factors. It is widely accepted that stroke increases dramatically with age and it is more likely to affect the elderly. Ischemic stroke is no longer a disease affecting just elderly people, one-fourth of ischemic strokes occurs in working-aged individuals and an estimated 3.6 million young people are affected each year. Approximately $10 \%$ of ischemic strokes occur in people aged less than 50 years ${ }^{7,8}$. Ischemic stroke at young age may be increasing further, since multiple recent studies have reported increasing incidence of ischemic strokes particularly at younger ages since 1980s, while incidence at older ages has been declining during the same peri$\mathrm{od}^{9-13}$. Higher stroke rates are noted in African Americans, Hispanic Americans and the Black race compared to the White one. In addition to common risk factors such as hypertension, diabetes, and smoking, recent studies have shown that genetic factors have important roles in the pathogenesis of ischemic stroke ${ }^{14,15}$. Higher prevalence of stroke is noted in Chinese and Japanese population ${ }^{4,5}$.

(C) 2019 Cui et al. Licensee African Health Sciences. This is an Open Access article distributed under the terms of the Creative commons Attribution License (https://creativecommons.org/licenses/BY/4.0), which permits unrestricted use, distribution, and reproduction in any medium, provided the original work is properly cited. 
Thus identification and management of possible risk factors to prevent stroke is an important strategy to reduce human and economic burden of ischemic stroke ${ }^{5}$.

This review discusses and summarizes the evidence for modifiable and non-modifiable risk factors in ischemic stroke and their association on Asian population.

\section{Methodology}

\section{Data identification and extraction}

We searched the PubMed, Google, MEDLINE, CNKI, VIP INFORMATION and Embase databases were searched up to April 2018 using ischemic stroke to identify all relevant literature on human studies. Furthermore, we searched the reference lists of reviews and retrieved articles manually. When the same patient population appeared in several publications, we chose the largest sample size. Data from each eligible study was extracted such as year of publication, first author name, ethnicity/country, number of ischemic stroke patients and healthy controls, modifiable and non-modifiable risk factors and reported associations. This meta-analysis included a total of 08 articles on modifiable and non-modifiable risk factors and ischemic stroke. Data were extracted independently from each study by using a pre-defined form and disagreements were resolved by discussion.

\section{Inclusion criteria}

The selected studies met the following criteria: well-designed case-control studies to evaluate the modifiable and non-modifiable factors and ischemic stroke risk.

\section{Exclusion criteria}

Studies were excluded if one of the following existed: non-Asian population; animal studies, reviews, case reports, abstracts and family-based studies.

\section{Statistical analysis}

Comprehensive meta-analysis (CMA) V.3 was employed for calculation of pooled standard errors and 95\% confidence interval (CIs). The standard differences in means were estimated for each study in a random-effect model. A chi-square-based $\mathrm{Q}$ test was used to measure between-study heterogeneity. Statistical significance was defined at $\mathrm{P}<0.01$. In addition, I2 statistic was calculated to quantify the proportion of the total variation across studies due to heterogeneity (I2 $=0 \%-25 \%$ : no heteroge $\neg$ neity; I2 $=25-50 \%$ : moderate heterogeneity; I2 $=50-75 \%$ : large heterogeneity; I2 $=75-100 \%$ : extreme heterogeneity) ${ }^{16}$. The ORs were pooled using the fixed effects model (Mantel-Haenszel method) ${ }^{17}$ when $\mathrm{P}>0.01$ and the random effects model (Der Simonian and Laird method $)^{18}$ if $\mathrm{P}<0.01$. Meta-analysis of the present studies yielded I 2 values of $>95 \%$, thus indicate significant heterogeneity. Subgroup analysis by ethnicity and sample size $(500-1000<500>1000)$ were performed to further identify heterogeneity.

\section{Results}

\section{Study characteristics}

A total of sixty-five papers were obtained by the publication search, among which eight met the inclusion criteria all in English (Fig 1). Eight meta-analyzed studies conducted in different parts of the world comparing modifiable and non-modifiable risk factors in ischemic stroke patients and healthy controls. After detailed evaluation of titles, abstracts and careful study of papers/articles, 08 eligible articles were screened for the meta-analysis, including 2611 confirmed ischemic stroke patients and 2833 healthy controls. The characteristics of the selected studies of cases and controls are shown in Table 1. The Q test and I2 statistics revealed heterogeneity among the included studies and thus a random-effects model was employed in analysis of all the modifiable and non-modifiable risk factors. Hence following risk factors were evaluated in ischemic patients and healthy controls to find out the overall association of the risk factors with ischemic patients. 


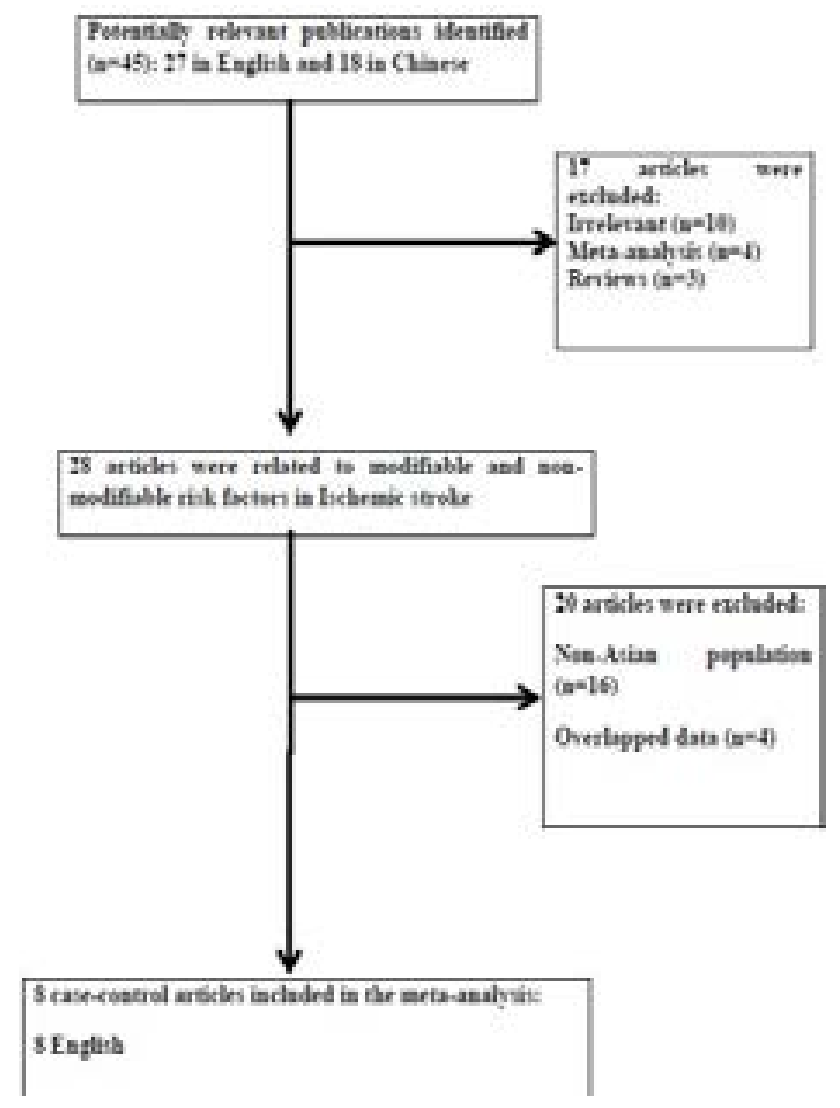

Fig 1: Flow chart

Table 1: The main characteristics of studies selected for meta-analysis and distribution of modifiable and non-modifiable risk factors in Ischemic stroke patients and healthy controls

\begin{tabular}{|c|c|c|c|c|c|c|c|c|c|c|c|c|c|}
\hline \multirow{2}{*}{$\begin{array}{l} \\
\text { First Author } \\
\text { (year) } \\
\text { (Case/Control) }\end{array}$} & \multirow[b]{2}{*}{$\begin{array}{l}\text { Country/ } \\
\text { Ethnicity }\end{array}$} & \multicolumn{6}{|c|}{ Ischemic stroke } & \multicolumn{6}{|c|}{ Healthy control } \\
\hline & & Age* & $\begin{array}{l}\text { Total } \\
\text { Cholesterol* }\end{array}$ & Triglyceride* $^{*}$ & HDL-C* & LDL-C* & Glucose ${ }^{*}$ & Age* & $\begin{array}{l}\text { Total } \\
\text { Cholesterol* }\end{array}$ & Triglyceride* & HDL-C* & LDL-C* & Glucose ${ }^{*}$ \\
\hline $\begin{array}{l}\text { ZHONG et al. } \\
(2017) \\
(300 / 300)\end{array}$ & China & 65.49 & 4.4 & 1.76 & 1.24 & 2.45 & - & 67.12 & 5.18 & 1.57 & 1.18 & 2.66 & - \\
\hline $\begin{array}{l}\text { Ming-Song et al. } \\
\text { (2009) } \\
(100 / 270)\end{array}$ & Taiwan & 70 & 187.14 & 141.32 & 41.06 & 117.9 & 119.43 & 63 & 183.28 & 105.39 & 42.63 & 124.55 & 109.81 \\
\hline $\begin{array}{l}\text { Minjie Shao et } \\
\text { al. }(2013) \\
(459 / 462)\end{array}$ & China & 68.56 & 4.73 & 1.79 & & 2.91 & - & 63.82 & 4.86 & 1.79 & & 3.03 & - \\
\hline $\begin{array}{l}\text { Wu et al. (2017) } \\
\text { (167/176) }\end{array}$ & Mongolia & 57.5 & 5.11 & 2.13 & 1.39 & 3.08 & - & 50.99 & 7.97 & 2.24 & 1.45 & 3.08 & - \\
\hline $\begin{array}{l}\text { Hua-Tuo et al. } \\
(2017) \\
(380 / 450)\end{array}$ & China & 60.7 & 5.29 & 2.09 & 1.31 & 2.98 & - & 63.9 & 4.86 & 1.54 & 1.69 & 2.31 & - \\
\hline $\begin{array}{l}\text { Hong Li et al. } \\
\text { (2017) } \\
(385 / 362)\end{array}$ & China & 62.3 & 5.35 & 1.89 & 1.35 & 3.08 & 6.25 & 69.01 & 5.4 & 1.62 & 1.48 & 2.85 & 5.93 \\
\hline $\begin{array}{l}\text { Satrupa et al. } \\
(2018) \\
(620 / 620)\end{array}$ & India & 51.3 & 194.2 & 173.4 & 49.5 & & 135.7 & 49.08 & 195.8 & 138.2 & 59.3 & - & \begin{tabular}{ll|}
119.4 \\
\end{tabular} \\
\hline $\begin{array}{l}\text { Murali et al. } \\
(2014) \\
(200 / 193)\end{array}$ & India & 57.5 & 207.8 & 195.4 & 43.7 & 130 & 154.1 & 56 & 170.4 & 150.9 & 37.2 & 97.4 & 106.2 \\
\hline
\end{tabular}

* Mean values

HDL-C $=$ high density lipid-cholesterol

LDL-C $=$ low density lipid-cholesterol

Age $=$ Years

Total Cholesterol, Triglyceride, HDL-C, LDL-C $=$ mmol/1

Glucose $=\mathrm{mg} / \mathrm{dl}$ 


\section{Triglyceride}

The levels of triglyceride were evaluated in 2611 confirmed ischemic stroke patients and 2833 controls. Overall data revealed significant heterogeneity $Q=160$,
$\mathrm{I} 2=95.62 \%, \mathrm{P}=0.00$ shown in Table 2 . Meta-analysis by Random- effects model showed significant association of triglyceride with ischemic stroke with pooled standard error $=0.13(-0.62-(-0.09), \mathrm{Z}=-2.65, \mathrm{P}=0.007$ as shown in Fig 2.

Table 2: Statistics to test publication bias and heterogeneity in the meta-analysis

\begin{tabular}{|c|c|c|c|c|c|c|c|c|}
\hline \multirow{2}{*}{$\begin{array}{l}\text { Number } \\
\text { of studies }\end{array}$} & \multirow{2}{*}{$\begin{array}{l}\text { Genotype } \\
\text { (Case/Control) }\end{array}$} & \multicolumn{4}{|c|}{ Effect size and $95 \%$ interval } & \multicolumn{3}{|c|}{ Heterogeneity analysis } \\
\hline & & $\begin{array}{l}\text { Std. } \\
\text { Error }\end{array}$ & $95 \% \mathrm{CI}$ & Z-Value & P value & Q-statistic & $\begin{array}{l}{ }_{\text {P-value }} \\
\text { (heterogeneity) }\end{array}$ & $b_{I}^{2}(\%)$ \\
\hline 08 & $\begin{array}{l}\text { Age } \\
(2611 / 2833)\end{array}$ & 0.15 & $(-0.36-0.25)$ & -0.34 & 0.72 & 218.04 & 0.00 & 96.78 \\
\hline 08 & $\begin{array}{l}\text { Total Cholesterol } \\
(2611 / 2833)\end{array}$ & 0.13 & $(-0.27-0.24)$ & -0.09 & 0.92 & 154.47 & 0.00 & 95.46 \\
\hline 08 & $\begin{array}{l}\text { Triglyceride } \\
(2611 / 2833)\end{array}$ & 0.13 & $(-0.62-(-0.09)$ & -2.65 & 0.008 & 160.00 & 0.00 & 95.62 \\
\hline 07 & $\begin{array}{l}\text { HDL-C } \\
(2152 / 2371)\end{array}$ & 0.18 & $(-0.20-0.53)$ & 0.85 & 0.39 & 219.12 & 0.00 & 97.26 \\
\hline 07 & $\begin{array}{l}\text { LDL-C } \\
(1991 / 2213) \\
\end{array}$ & 0.15 & $(-0.44-0.14)$ & -1.00 & 0.31 & 134.30 & 0.00 & 95.53 \\
\hline 04 & $\begin{array}{l}\text { Glucose } \\
(1305 / 1445)\end{array}$ & 0.23 & $(-1.08-(-0.14)$ & -2.56 & 0.01 & 96.33 & 0.00 & 96.88 \\
\hline
\end{tabular}

$\mathrm{CI}=$ confidence interval; $\mathrm{Chi}^{2} \mathrm{Q}$-statistic for homogeneity in Random-effects model ${ }^{\mathrm{a}} \mathrm{P}$-value for the Q-statistic in random-effect model ${ }^{\mathbf{b}}$ Higgins $\mathrm{I}^{2}$-statistic for heterogeneity in random-effect model

HDL-C $=$ high density lipid-cholesterol

LDL-C $=$ low density lipid-cholesterol

Age $=$ Years

Total Cholesterol, Triglyceride, HDL-C, LDL-C $=$ mmol/ 1

Glucose $=\mathrm{mg} / \mathrm{dl}$ 


\begin{tabular}{|c|c|c|c|c|c|c|c|c|c|c|c|}
\hline \multirow[t]{2}{*}{ Bud nore } & \multicolumn{7}{|c|}{ zixutics to each nower. } & \multirow{2}{*}{\multicolumn{4}{|c|}{ 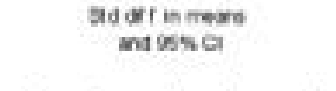 }} \\
\hline & $\begin{array}{l}\text { Sid diff } \\
\text { in meass }\end{array}$ & $\begin{array}{l}\text { Standact } \\
\text { efror }\end{array}$ & Vanance & $\begin{array}{l}\text { Lover } \\
\text { limit }\end{array}$ & $\begin{array}{l}\text { Upper } \\
\text { umat }\end{array}$ & z.Vates & evalue & & & & \\
\hline Dechod ext AL 5017 & -017 & o.ces & $0.00 t$ & 0207 & 0.005 & -1000 & 0.000 & & $=$ & & \\
\hline 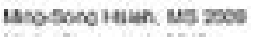 & -0505 & Q 110 & 0.014 & orea & 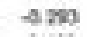 & 445 & 0,000 & & & & \\
\hline Write bhoo et at 2013 & 0.000 & 0.006 & 0.004 & 0.129 & 0.120 & 0.000 & 2000 & & & & \\
\hline Q Wuet al 2013 . & o ond & 8,96 & $001 z$ & $\Delta 147$ & Q 25 & $0 \operatorname{sen}$ & $a 00 t$ & & & $=$ & \\
\hline Hus Tie reisn at a zery & -9.40 & 0000 & 6006 & $46 \times 0$ & -200 & $4+2 t$ & $a+00$ & & & & \\
\hline knoue a 2017 & $\rightarrow a x$ & Dors & 0.005 & asas & -400 & $2 \pi 0$ & 0.006 & & & & \\
\hline Sanne Cas a a put & 284 & 0.060 & 0.004 & $+1,041$ & 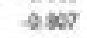 & -15 ed & 0.000 & & & & \\
\hline \multirow[t]{3}{*}{ Bund Wta an et a 2014} & -674 & 6.104 & 0.011 & $\Delta, 020$ & 4512 & $-6 \mathrm{kt}$ & 0,000 & & & & \\
\hline & -236 & 0.136 & 0013 & 8024 & $\Delta \omega t$ & 2000 & 0000 & 1 & & & \\
\hline & & & & & & & & a.ss & -0.430 .00 & a.s & 0.25 \\
\hline
\end{tabular}

Triabcerides(mmolt)

CaselControl

\begin{tabular}{|c|c|c|c|c|c|c|c|c|c|c|}
\hline \multirow[t]{2}{*}{ ghin nume } & \multicolumn{7}{|c|}{ grags ter exh inis. } & \multirow{2}{*}{\multicolumn{3}{|c|}{$\begin{array}{l}\text { sto at in mesns } \\
\text { and WES C }\end{array}$}} \\
\hline & $\begin{array}{c}\text { Se dir } \\
\text { in meass }\end{array}$ & $\begin{array}{c}\text { Sosogera } \\
\text { errot }\end{array}$ & Vanance & $\begin{array}{l}\text { Lower } \\
\text { limen }\end{array}$ & upoer & 2value & p. value & & & \\
\hline DHCWG ET $\alpha$. 2017 & 0751 & 0064 & $0 \infty 0 \%$ & oses & $Q \$ 17$ & Exs & 0.000 & & & I \\
\hline Unosing rein MS 2006 & e. .98 & 0.17 & 0.014 & .8237 & 0.122 & 0.000 & 0.280 & & & \\
\hline Unje Shoo of a 2013 & 0000 & 0000 & $Q 064$ & $\$ 000$ & 0225 & 1254 & 0.105 & & & \\
\hline Q Wu it $x 2017$ & 0.113 & 0.100 & 0.012 & 0.000 & $0 x$ & 1.097 & 0.200 & & & \\
\hline Wastub rashe ef a 2017 & ajos & 0070 & $a \propto 05$ & 0513 & $-6 z y$ & -5331 & 0000 & & & \\
\hline Mene U te a 20\%? & 9090 & 0073 & 0,00 & 0.006 & 0.192 & 0.060 & 0.512 & & & \\
\hline Emupoos of a 2018 & 0099 & 005 & Q $\infty 00$ & 8004 & 9.14 & 0.60 & 0.516 & & & 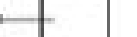 \\
\hline \multirow[t]{4}{*}{ Lurai Wiaran et a 2614} & 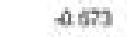 & Q 104 & a 911 & sate & 440 & $-6 \Delta x$ & 000 & & & \\
\hline & Q one & 0.12 & 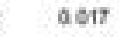 & 0.271 & $0: 4$ & $+0,000$ & 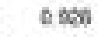 & & & \\
\hline & & & & & & & & 0.25 & 0.130 .00 & $0.13 \quad 0.25$ \\
\hline & & & & & & & & & case & centrol \\
\hline
\end{tabular}

Total Crolesterd inmoli

Fig 2: Forest plots showing effect of triglycerides and total cholesterol on ischemic stroke.

\section{Total Cholesterol}

Total cholesterol was analyzed in 2611 ischemic stroke patients and 2833 controls and a significant heterogeneity was observed with $\mathrm{Q}=154.47, \mathrm{I} 2=95.46 \%, \mathrm{P}=0.00$ shown in Table 2. Meta-analysis of the above mentioned samples showed non-significant association of total cholesterol with ischemic stroke having pooled standard error $=0.13(-0.27-0.24), \mathrm{Z}=-0.09, \mathrm{P}=0.92$ shown in Fig 2.

\section{High density lipid-cholesterol (HDL-C)}

Ratio of ischemic stroke patients andcontrols with respect to high density lipid-cholesterol (HDL-C) was 2152/2371. There was significant heterogeneity with $\mathrm{Q}=219.12$, I2 $=97.26 \%, \mathrm{P}=0.00$ shown in Table 2 . Meta-analysis of the high density lipid-cholesterol (HDL-C) levels between ischemic stroke patients and healthy controls showed non-significant results with pooled standard error $=0.18(-0.20-0.53), \mathrm{Z}=0.85, \mathrm{P}=0.39$ shown in Fig 3 . 


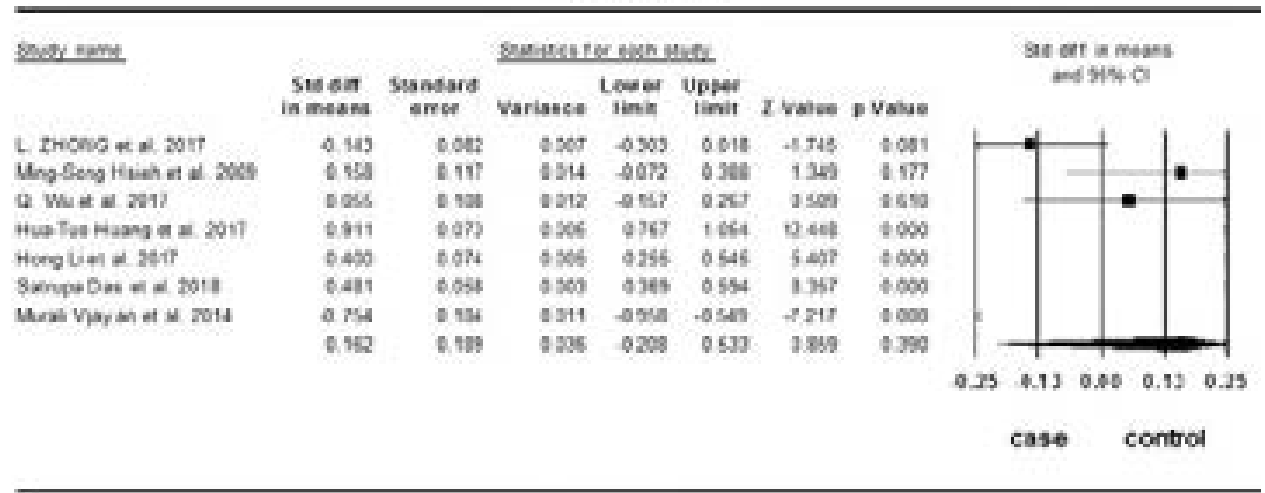

Ho.

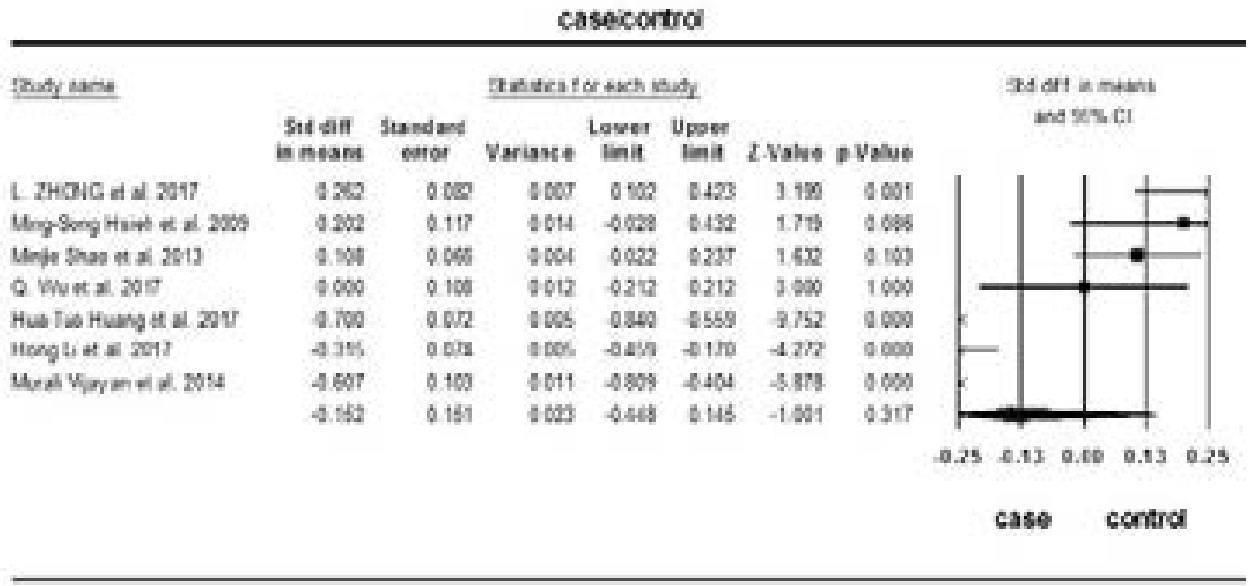

\section{LDLC (mmol)}

Fig 3: Forest plots showing effect of High Density Lipid-Cholesterol (HDL-C) and Low Density Lipid-Cholesterol (LDL-C) on ischemic stroke.

\section{Low density lipid-cholesterol (LDL-C)}

Ratio of ischemic stroke patients and controls with respect to low density lipid-cholesterol (LDL-C) was $1991 / 2213$. There was significant heterogeneity with $\mathrm{Q}=134.30, \mathrm{I} 2=95.53 \%, \mathrm{P}=0.00$ shown in Table 2. Meta-analysis of low density lipid-cholesterol (LDL-C) levels between ischemic stroke patients and healthy controls showed non-significant results with pooled standard error $=0.15(-0.44-0.14), Z=-1.00, P=0.31$ as shown Fig 3 .

\section{Glucose}

Ratio of ischemic stroke patients and controls were 1305/1445. There was significant heterogeneity $Q=96.33$,
$\mathrm{I} 2=96.88 \%, \mathrm{P}=0.00$ shown in Table 2. Meta-analysis of glucose levels between ischemic stroke patients and healthy controls showed significant results with pooled standard error $=0.23(-1.08-(-0.14), \mathrm{Z}=-2.56, \mathrm{P}=0.01$ as shown in Fig 4.

\section{Age}

2611 ischemic stroke patients and 2833 controls with respect to age were analyzed for heterogeneity and significant heterogeneity among studies was observed with $\mathrm{Q}=218.04, \mathrm{I} 2=96.78 \%, \mathrm{P}=0.00$ as indicated in Table 2. Meta-analysis of the age in all cases and controls revealed non-significant results with pooled standard error $=0.15$ (-0.36-0.25), $\mathrm{Z}=-0.34, \mathrm{P}=0.72$ as shown in Fig 4. 

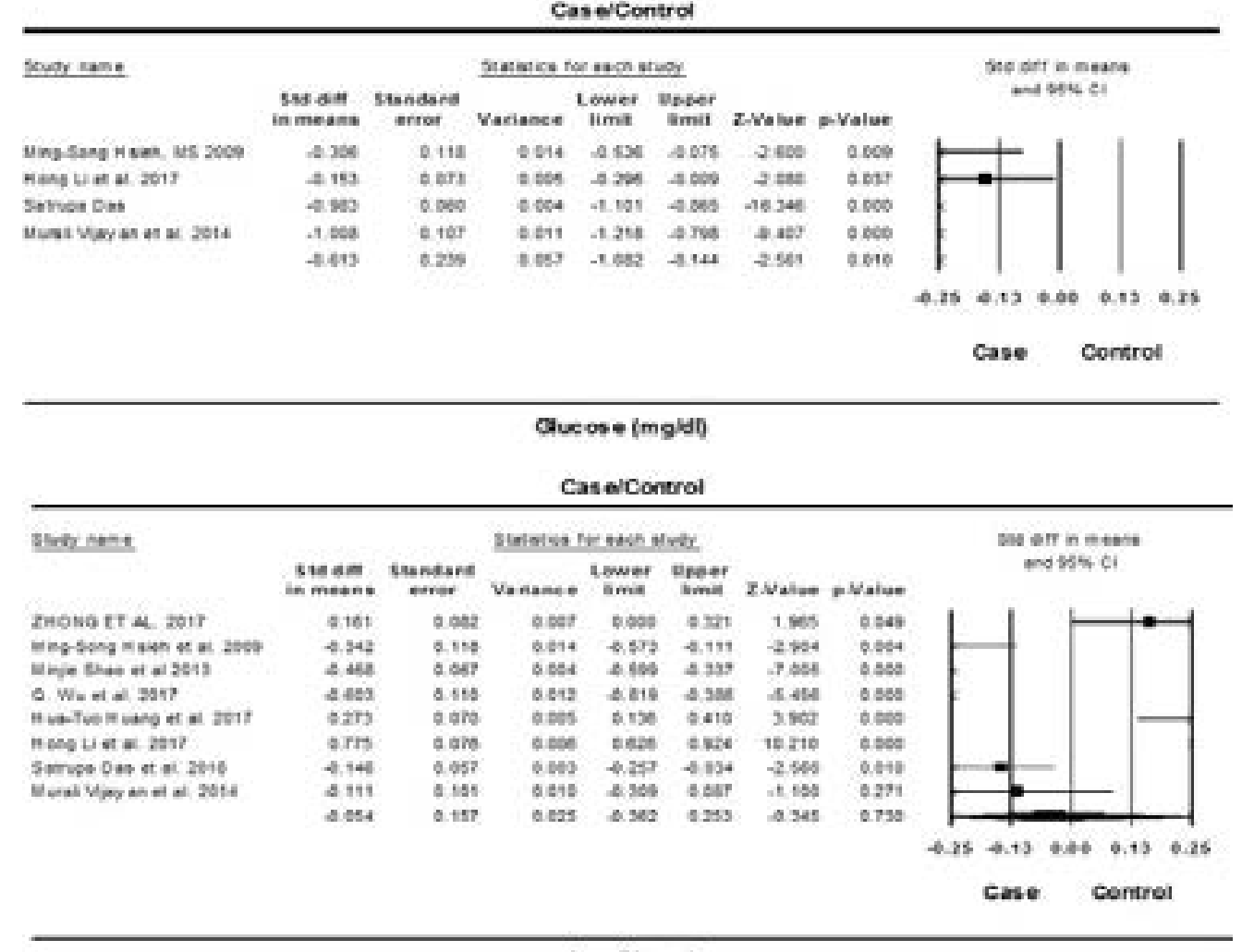

Age (Years)

Fig 4: Forest plots showing effect of Glucose and age on ischemic stroke.

\section{Discussion}

This present meta-analysis was undertaken to ascertain the role of modifiable and non-modifiable risk factors on ischemic stroke in Asian population. Therefore relevant data was searched on ischemic stroke viz-a-viz modifiable and non-modifiable risk factors. By comparing the results published before and in the present study, we found great interest in the present meta-analysis.

In a systematic review of cohort studies with ischemic stroke sub-type specific follow-up data on death and recurrent stroke ${ }^{19}$ the risk of a lacunar recurrence following a lacunar event at baseline was twice as great as the risk of lacunar recurrence following a non-lacunar event at baseline. Hypertension and diabetes were significant factors associated with recurrent lacunes, whereas hyperlipidaemia had a protective role. Recurrent lacunar infarction, especially in the case of multiple episodes of recurrent lacunes, may alert to the presence of cognitive impairment $^{20}$.
Ischemic stroke is a clinical syndrome with various genetic and clinical risk factors including age, cholesterol, triglyceride, HDL-C, LDL-C and glucose. Case-control studies are commonly used to find the association between the risk factors and the complex human diseases. A recent meta-analysis suggests that the association of lipoprotein (a) and ischemic stroke is stronger for young adults aged $<55$ years than for older individuals ${ }^{21}$. A Dutch study showed a fourfold higher mortality for young patients with ischemic stroke compared to age and sex matched background population, with excess mortality present across all age groups, but particularly for those aged 35-50 years ${ }^{22}$. The best UK data on stroke project shows incidence rate for first stroke is 1.6 per 1000 person years ${ }^{23}$.

The presence of sleep apnea is also a risk factor for stroke. Sleep apnea may increase the risk of stroke by leading to or worsening hypertension or ischemic heart disease. Asymptomatic vascular disorders may be viewed as subclinical arterial markers related to cardiovascular risk factors, 
and are predictors of stroke, myocardial infarction and vascular death in the mid- and long-term. ${ }^{24}$

This meta-analysis examined all the available studies on the association between modifiable and non-modifiable risk factors and ischemic stroke risk, including a total of 2611 ischemic patients and 2833 healthy control subjects. Although the pooled results showed that age, total cholesterol, HDL-C and LDL-C were not associated with the risk of ischemic stroke, the trend to an increased risk of developing ischemic stroke was observed due to high glucose $(\mathrm{P}=0.01)$ and triglyceride levels $(\mathrm{P}=0.008)$. Regarding cholesterol and its components, an association between low high-density lipoprotein cholesterol and ischemic stroke at young age has been demonstrated 25-27 but no clear association has been shown for total cholesterol, low-density lipoprotein cholesterol, or triglycerides. However, we could draw an interesting conclusion from that the more studies were included; the higher risk of developing ischemic stroke was indicated in the results. The overall heterogeneity between studies was very high for ischemic stroke risk factors like age, total cholesterol, triglyceride, HDL-C, LDL-C and glucose levels as indicated by $\mathrm{I} 2$ value of $>95 \%$ and as such no publication bias was detected within studies included in the meta-analysis.

This meta-analysis had some limitations. First, that only eight papers were included and also confounders were not included in the analysis, even though we tried to find as many studies as we could, assessed the literature carefully and used statistical methods to minimize the publication bias. Second, the number of subjects involved in our meta-analysis was limited. Thus, studies with larger sample size and high quality are needed to demonstrate our conclusions in future.

\section{Conclusion}

Meta-analysis of modifiable and non-modifiable risk factors like total cholesterol, high density lipid-cholesterol (HDL-C), low density lipid-cholesterol (LDL-C) and age were not independent risk factors for ischemic stroke; however triglyceride and glucose levels were proved as risk factors for ischemic stroke. Therefore present meta-analysis identified the importance of modifiable risk factors on ischemic stroke predisposition in Asian population.

\section{Conflict of interest}

None declared.

\section{References}

1. Dichgans M. Genetics of ischaemic stroke. Lancet Neurol. 2007; 6:149-61. PubMed.

2. Krupinski J, Kaluza J, Kumar P, Kumar S, Wang JM. Role of angiogenesis in patients with cerebral ischemic stroke. Stroke. 1994; 25:1794-8. PubMed.

3. Lai SM, Alter M, Friday G, Sobel E. A multifactorial analysis of risk factors for recurrence of ischemic stroke. Stroke. 1994; 25:958-62. PubMed.

4. Goldstein LB, Adams R, Becker K, Furberg CD, Gorelick PB, Hademenos G, Hill M, Howard G, Howard VJ, Jacobs B, Levine SR, Mosca L, Sacco RL, Sherman DG, Wolf PA, del Zoppo GJ. Primary prevention of ischemic stroke: A statement for healthcare professionals from the Stroke Council of the American Heart Association. Circulation. 2001; 103:163-82 PubMed.

5. Warlow C, Sudlow C, Dennis M, Wardlaw J, Sandercock P. Stroke. Lancet. 2003;362:1211-24. PubMed.

6. Goldstein LB, Adams R, Alberts MJ, Appel LJ, Brass LM, Bushnell CD, Culebras A, Degraba TJ, Gorelick PB, Guyton JR, Hart RG, Howard G, Kelly-Hayes M, Nixon JV, SaccoRL. Primary prevention of ischemic stroke: a guideline from the American Heart Association/American Stroke Association Stroke Council: cosponsored by the Atherosclerotic Peripheral Vascular Disease Interdisciplinary Working Group; Cardiovascular Nursing Council; Clinical Cardiology Council; Nutrition, Physical Activity, and Metabolism Council; and the Quality of Care and Outcomes Research Interdisciplinary Working Group: the American Academy of Neurology affirms the value of this guideline. Stroke. 2006; 37:1583-633. PubMed .

7. Putaala J, Metso AJ, Metso TM, Konkola N, Kraemer Y, Haapaniemi E, Kaste M, Tatlisumak T. Analysis of 1008 consecutive patients aged 15 to 49 with first-ever ischemic stroke: the Helsinki young stroke registry. Stroke. 2009; 40:1195-203. PubMed.

8. Maaijwee NA, Rutten-Jacobs LC, Schaapsmeerders P, van Dijk EJ, de Leeuw FE. Ischaemic stroke in young adults: risk factors and long-term consequences. Nat Rev Neurol. 2014; 10:315-25. PubMed.

9. Rosengren A, Giang KW, Lappas G, Jern C, Toren K, Bjorck L. Twenty-four-year trends in the incidence of ischemic stroke in Sweden from 1987 to 2010. Stroke. 2013; 44:2388-93. PubMed. 
10. George MG, Tong X, Kuklina EV, Labarthe DR. Trends in stroke hospitalizations and associated risk factors among children and young adults, 1995-2008. Ann Neurol. 2011; 70:713-21. PubMed.

11. Kissela BM, Khoury JC, Alwell K, Moomaw CJ, Woo D, Adeoye O, Flaherty ML, Khatri P, Ferioli S, De Los Rios La Rosa F, Broderick JP, Kleindorfer DO. Age at stroke: temporal trends in stroke incidence in a large, biracial population. Neurology 2012; 79:1781-7. PubMed.

12. Vangen-Lonne AM, Wilsgaard T, Johnsen SH, Carlsson M, Mathiesen EB. Time trends in incidence and case fatality of ischemic stroke: the tromso study 1977-2010. Stroke. 2015; 46:1173-9. PubMed.

13. BejotY, Daubail B, Jacquin A, Durier J, Osseby GV, Rouaud O, Giroud M. Trends in the incidence of ischaemic stroke in young adults between 1985 and 2011: the Dijon Stroke Registry. J Neurol Neurosurg Psychiatry. 2014; 85:509-13. PubMed.

14. Humphries SE, Morgan L. Genetic risk factors for stroke and carotid atherosclerosis: insights into pathophysiology from candidate gene approaches. Lancet Neurol 2004; 3:227-35. PubMed.

15. Song Y, Long Y, Long L, Zhang N, Liu Y. Polymorphism Ala54Thr of fatty acid-binding protein 2 gene is not associated with stroke risk in Han population of $\mathrm{Hu}-$ nan China. Med Sci Monit. 2014; 20:1751-7. PubMed.

16. Higgins JP, Thompson SG, Deeks JJ, Altman DG. Measuring inconsistency in meta-analyses. BMJ 2003; 327:557-60. PubMed.

17. Mantel N, Haenszel W. Statistical aspects of the analysis of data from retrospective studies of disease. $J$ Natl Cancer Inst 1959; 22:719-48. PubMed.

18. DerSimonian R, Laird N. Meta-analysis in clinical trials. Control Clin Trials 1986; 7:177-88. PubMed.

19. Jackson C, Sudlow C. Comparing risks of death and recurrent vascular events between lacunar and non-lacunar infarction. Brain 2005; 128:2507-17. PubMed.

20. Arboix A, Font A, Garro C, Garcia-Eroles L, Comes E, Massons J. Recurrent lacunar infarction following a previous lacunar stroke: a clinical study of 122 patients. $J$ Neurol Neurosurg Psychiatry 2007; 78:1392-4.

21. Nave AH, Lange KS, Leonards CO, Siegerink B, Doehner W, Landmesser U, Steinhagen-Thiessen E, Endres M, Ebinger M. Lipoprotein (a) as a risk factor for ischemic stroke: a meta-analysis. Atherosclerosis 2015; 242:496-503. PubMed.

22. Rutten-Jacobs LC, Arntz RM, Maaijwee NA, Schoonderwaldt HC, Dorresteijn LD, van Dijk EJ, de Leeuw FE. Long-term mortality after stroke among adults aged 18 to 50 years. JAMA 2013; 309:1136-44. PubMed. 23. Wahlgren N, Ahmed N, Davalos A, Hacke W, Millan M, Muir K, Roine RO, Toni D, Lees KR. Thrombolysis with alteplase 3-4.5 h after acute ischaemic stroke (SITS-ISTR): an observational study. Lancet 2008; 372:1303-9. PubMed.

24. Arboix A. Cardiovascular risk factors for acute stroke: Risk profiles in the different subtypes of ischemic stroke. World J Clin Cases 2015; 3:418-29. PubMed.

25. Lipska K, Sylaja PN, Sarma PS, Thankappan KR, Kutty VR, Vasan RS, Radhakrishnan K. Risk factors for acute ischaemic stroke in young adults in South India. $J$ Neurol Neurosurg Psychiatry 2007; 78:959-63.

26. Albucher JF, Ferrieres J, Ruidavets JB, Guiraud-Chaumeil B, Perret BP, Chollet F. Serum lipids in young patients with ischaemic stroke: a case-control study. J Neurol Neurosurg Psychiatry 2000; 69:29-33.

27. Bandasak R, Narksawat K, Tangkanakul C, Chinvarun Y, Siri S. Association between hypertension and stroke among young Thai adults in Bangkok, Thailand. Southeast Asian J Trop Med Public Health 2011; 42:1241-8. 